\title{
PENERAPAN MODEL PEMBELAJARAN KOOPERATIF TIPE STAD UNTUK MENINGKATKAN KEMAMPUAN MENULIS SURAT UNDANGAN SISWA KELAS V SDN 11 LOGHIA
}

\author{
Asni ${ }^{1)}$, Mansyur. $\mathrm{M}^{2)}$. \\ 1) SDN 11 Loghia, Muna, Indonesia \\ 2) Jurusan PGSD, Universitas Halu Oleo, Kendari, Indonesia \\ email: mansyurm919@gmail.com
}

\begin{abstract}
Abstrak: Jenis penelitian adalah penelitian tindakan kelas yakni adanya tindakantindakan tertentu untuk memperbaiki proses belajar mengajar di kelas. Sujek penelitian ini adalah siswa kelas V SD Negeri 11 Loghia pada semester I Tahun pelajaran 2016/2017 dengan jumlah siswa 22 orang. Sumber data yaitu guru dan siswa. Pelaksanaan PTK ini terdiri dari 2 siklus, masing-masing siklus dilaksanakan dalam 2 kali pertemuan. Adapun prosedur penelitian ini adalah: (1) perencanaan, (2) pelaksanaan tindakan, (3) observasi, (4) evaluasi, (5) refkelsi. Hasil penelitian menunjukkan bahwa kemampuan menulis surat undangan siswa kelas V SD Negeri 11 Loghia standar kompetensi menulis surat undangan dapat ditingkatkan melalui model pembelajaran kooperatif tipe STAD. Hal ini dibuktikan dengan hasil belajar siswa pada tahun 2016/2017 hanya mencapai $62 \%$ meningkat setelah melakukan PTK siklus I ketuntasan belajar mencapai 72,73\% dengan nilai rata-rata 63,03 dan pada siklus II meningkat menjadi 90,91\% dengan nilai rata-rata 81,81 . Aktivitas mengajar guru juga meningkat pada siklus I dari 22 aspek yang diamati 16 aspekatau $72,73 \%$ yang terlaksana pada siklus II keseluruhan aspek yang diamati telah terlaksana dengan maksimal, selanjutnya aktivitas belajar siswa siklus I dari 16 aspek diamati 7 aspek atau $43,75 \%$ yang terlaksana dan pada siklus II keseluruhan aspek yang diamati telah terlaksana dengan maksimal.
\end{abstract}

Kata kunci: Model Pembelajaran Kooperatif; Tipe STAD; Kemampuan Menulis.

\section{APPLICATION OF COOPERATIVE LEARNING MODEL STAD TO IMPROVE STUDENT WRITING ABILITY LETTER OF INVITATION CLASS V SDN 11 LOGHIA}

Abstract: This type of research is classroom action research, namely the existence of certain actions to improve the teaching and learning process in the classroom. The objective of this research was the fifth grade students of SD Negeri 11 Loghia in the first semester of the 2016/2017 academic year with 22 students. The data sources were teachers and students. The implementation of this CAR consists of 2 cycles, each cycle carried out in 2 meetings. The procedures for this research are: (1) planning, (2) action, (3) observation, (4) evaluation, (5) reflection. The results showed that the ability to write invitation letters of grade V SD Negeri 11 Loghia competency standards in writing invitation letters could be improved through the STAD type cooperative learning model. This is evidenced by the results of student learning in 2016/2017 only reached 62\% increased after doing the first cycle of learning completeness reached $72.73 \%$ with an average value of 63.03 and in the second cycle increased to $90.91 \%$ with an average value. -average 81.81 . Teacher teaching activities also increased in cycle I from 22 observed aspects of 16 aspects or $72.73 \%$ which were carried out in cycle II, all observed aspects had been maximized, then student learning activities in cycle I from 16 aspects were observed to be 7 aspects or $43.75 \%$ that has been implemented and in cycle II all observed aspects have been maximized.

Key words: Cooperative Learning Model; STAD type; Teacher Activities; Student Activities; Writing Skills 


\section{Pendahuluan}

Keterampilan menulis surat di sekolah merupakan suatu tempat penyelenggaraan pendidikan yang memiliki peranan dalam menciptakan Sumber Daya Manusia (SDM) yang berkualitas melalui mendidik, membimbing, melatih dan mengajar peserta didik dalam upaya mengembangkan kemampuan menulis surat dengan menggunakan kalimat efektif dengan baik dan benar.

Sekolah Dasar (SD) sebagai suatu lembaga formal yang memberikan pengetahuan dasar baik berupain telektual (kognitif), sikap (efektif) dan keterampilan (psikomotorik). Surat itu merupakan alat komunikasi yang tertulis dalam bentuk secarik kertas yang berisi keterangan untuk berbagai maksud dan tujuan sehingga Sekolah Dasar mempelajari tentang menulis surat undangan, baik resmi maupun tidak resmi (Depdiknas 2004: 9).

Dalam kegiatan belajar mengajar di sekolahk hususnya di SD, banyak kendala yang menjadi penyebab sehingga siswa mengalami kesulitan dalam belajar. Baik itu dalam memahami konsep maupun menerapkan konsep yang adaatau yang diberikanoleh guru. Dalam kesulitan belajar ini, ada dua faktor yang mempengaruhi yaitu faktor internal yaitu faktor yang berasal dari dalam diri siswa itu sendiri dan faktor eksternal atau faktor yang timbul karena adanya pengaruh dari lingkungan sekitar.

Berdasarkan hasil pengalaman saya mengajar di kelas V (Lima) SD Negeri 11 Loghia terdapat berbagai macam masalah yang ada pada siswa yang ditemukan oleh guru di dalam kelas. Adapun masalah yang timbul ketika proses pembelajaran berlangsung yaitu kurangnya motivasi yang ada pada diri siswa dalam belajar. Hal ini terbukti disaat proses pembelajaran berlangsung masih banyak siswa yang tidak memperhatikan penjelasan guru, misalnya bermain, bercerita, mengganggu temannya. Selain itu, siswa yang mempunyai kemampuan yang lebih sangat mendominasi pembelajaran sehingga mengakibatkan siswa yang berkemampuan rendah menjadi pasif. Hal ini disebabkan karena pertanyaan-pertanyaan yang diberikan oleh guru dapat dengan mudah dijawab oleh siswa yang mempunyai kemampuan atau kecakapan lebih.

Namun demikian, tidak semua masalah yang timbul di dalam kelas diakibatkan oleh siswa. Berdasarkan hasil observasi di SD Negeri 11 Loghia, hasil yang ditemukan bahwa dalam proses pembelajaran guru kurang kreatif mengelola kelasnya serta lebih mendominasi proses pembelajaran sehingga menyebabkan siswa cenderung pasif. Selain itu, siswa tidak berani mengeluarkan pendapat sehingga siswa kurang kreatif mengembangkan pemikirannya dalam menyelesaikan masalah yang mereka hadapi pada akhirnya berdampak pada rendahnya hasil belajar bahasa Indonesia.

Berdasarkan informasi yang diperoleh dari guru kelas V SD Negeri 11 Loghia, bahwa pada Tahun Pelajaran 2015/2016 nilai rata-rata yang diperoleh siswa adalah 62. Nilai tersebut belum memenuhi Kriteria Ketuntasan Minimal (KKM) yang ditetapkan oleh sekolah yakni 65.

Dari uraian di atas, maka diperlukan suatu model atau metode pembelajaran yang menunjang keberhasilan pembelajaran. Adapaun salah satu alternative dalam menjawab masalah-masalah yang ada dalam proses pembelajaran yakni dengan menerapkan model pembelajaran kooperatif tipe STAD (Student Teams Achievement Divisions) dalam meningkatkan hasil belajar Bahasa Indonesia siswakelas V SD Negeri 11 Loghia.

Pada pembelajaran kooperatif tipe STAD (Student Teams Achievement Divisions) siswa belajar dengan menggunakan kelompok kecil yang anggotanya heterogen dan menggunakan lembar kegiatan atau pembelajaran untuk menuntaskan materi pembelajaran, kemudian saling membantu satu sama lain untuk memahami bahan pembelajaran melalui fotorial, kuis satu sama lain dan atau melakukan diskusi. Metode kooperatif tipe STAD dapat meningkatkan aktivitas, kerja sama, kepercayaan diri, dan hasil belajar siswa Adesoji \& 
Ibraheem (Pujiati, dkk. 2015). Lima komponen pembelajaran kooperatif tipe STAD menurut Slavin (Utami, 2106) adalah: (1) presentasi kelas, (2) kerja tim, (3) kuis, (4) penghargaan individu dan (5) penghargaan kelompok.

Menurut Soewarso (1998: 23) terdapat kekurangan dalam pembelajaran Kooperatif tipe STAD (Student Teams Achievement Divisions) yaitu, Pembelajaran Kooperatif bukanlah solusi yang baik untuk memecahkan masalah yang timbul dalam kelompok kecil dan adanya ketergantungan siswa yang lambat berpikir sehingga pembelajaran kooperatif memerlukan waktu yang lama, sehingga target pencapaian kurikulum tidak dapat terpenuhi.Pembelajaran Kooperatif tidak dapat menerapkan materi pelajaran secara cepat, dan penelaian terhadap individu, kelompok, dalam memberian hadiah menyulitkan bagi guru untuk melaksanakanya.

Penelitian yang dilakukan Juraini (2016) menunjukan terdapat pengaruh model pembelajaran kooperatif tipe STAD dengan metode eksperimen terhadap keterampilan proses sains fisika pada siswa SMA Negeri 1 Labuapi tahun pelajaran 2015/2016.

Kelebihan pembelajaran Kooperatif tipe STAD menurut Davidson (Nur Asma, 2006: 26) yaitu, dapat meningkatkan kecakapan individu dan meningkatkan kecakapan kelompok, meningkatkan komitmen, menghilangkan prasangka buruk terhadap teman sebaya, tidak bersifat kooperatif, dan tidak memiliki rasa dendam

Melalui penerapan model pembelajaran kooperatif tipe STAD (Student Teams Achievement Divisions) diharapkan dapat memberikan nuansa baru dalam kinerja guru bahasa Indonesia, mengoptimalkan aktivitas belajar siswa sehingga pada akhirnya hasil belajar bahasa Indonesia siswa juga akan meningkat. Berdasarkan uraian di atas, maka peneliti tertarik untuk melakukan Penelitian Tindakan Kelas (PTK) dengan judul "Penerapan Model Pembelajaran Kooperatif Tipe STAD (Student Teams Achievement Divisions) untuk Meningkatkan Kemampuan Menulis Surat Undangan Siswa Kelas V SD Negeri 11 Loghia."

Masalah dalam penelitian ini adalah: apakah penerapan model pembelajaran kooperatif tipe STAD dapat meningkatkan kemampuan menulis surat undangan siswa kelas V SD Negeri 11 Loghia? Tujuan penelitian ini adalah untuk meningkatkan kemampuan menulis surat undangan melalui penerapan model pembelajaran kooperatif tipe STAD siswa kelas V SD Negeri 11 Loghia. Penelitian ini diharapkan dapat memberikan manfaat bagi guru, siswa, sekolah dan penelitian lainnya.

\section{Metode}

Jenis penelitian adalah penelitian tindakan kelas (PTK. Penelitian ini dilaksanakan pada semester ganjil tahun ajaran 2016/2017 dan bertempat di kelas V SD Negeri 11 Loghia. dengan Subyek dalam penelitian ini adalah adalah guru dan siswa kelas V SD Negeri 11 Loghia yang terdaftar pada tahun ajaran 2016/2017 dengan jumlah siswa 22. Penelitian tindakan kelas ini dilaksanakan dalam dua siklus yang terdiri dari empat tahapan yaitu perencanaan, pelaksanaan tindakan, observasi dan evaluasi serta refleksi Jenis data dalam penelitian ini adalah data kualitatif dan kuantitatif. Data kualitatif berupa kegiatan proses pembelajaran aktivitas belajar siswa dan aktivitas guru. Data kuantitatif berupa nilai hasil belajar siswa. Sumber data dalam penelitian ini adalah guru dan siswa Kelas V SD Negeri 11 Loghia.

Data kualitatif akan dianalisis secara deskriptif kualitatif berdasarkan observasi, sedangkan data kuantitatif dianalisis secara kuantitatif menggunakan rumus:

1. Seorang siswa dikatakan tuntas secara individual jika siswa tersebut telah memperoleh nilai minimal 65.

$$
\text { NilaiAkhir }=\frac{\text { Skorperolehansiswa }}{\text { skortotal }} \times 100
$$


2. Untuk mengetahui persentase ketuntasan secara klasikal, digunakan rumus :

$$
\frac{\text { Jumlah siswa yang memperoleh nilai } \geq 65}{\text { Jumlah siswa yang mengikuti tes }} \times 100 \%
$$

Indikator keberhasilan dalam penelitian ini adalah 1) Aktivitas belajar siswa baik secara individu maupun kelompok berada pad akategori baik ( $\geq 65)$. 2) Hasil belajar menulis surat undangan siswa dikatakan tuntas jika $75 \%$ dari jumlah siswa telah mencapai $\geq 65$

\section{Hasil}

1. Aktivitas Guru

Berdasarkan hasil observasi siswa siklus I, maka diperoleh presentase pelaksanaan skenario pembelajaran sebagai berikut:

Tabel 1. Hasil Observasi terhadap Aktivitas Guru Siklus I

\begin{tabular}{cccc}
\hline Aspek-Aspek Yang Diobservasi & Ya & Tidak & Komentar \\
\hline Jumlah skor & 16 & 6 \\
\hline Persentase & 72,73 & 27,27 \\
\hline Ketuntasan & \multicolumn{3}{c}{ Belum tuntas } \\
\hline
\end{tabular}

Tabel 2. Hasil Observasi terhadap Aktivitas Guru Siklus II

\begin{tabular}{cccc}
\hline Aspek-Aspek Yang Diobservasi & Ya & Tidak & Komentar \\
\hline Jumlah skor & 22 & - & \\
\hline Persentase & 100 & - & \\
\hline Ketuntasan & \multicolumn{3}{c}{ Tuntas } \\
\hline
\end{tabular}

2. Aktivitas Siswa

Berdasarkan hasil observasi siswa siklus I, maka diperoleh presentase aktivitas siswa sebagai berikut:

Tabel 3. Aktivitas Kegiatan Siswa Siklus I

\begin{tabular}{cccc}
\hline Aspek-Aspek Yang Diobservasi & Ya & Tidak & Komentar \\
\hline Jumlah skor & 7 & 9 \\
\hline Persentase & 43,75 & 56,25 \\
\hline Ketuntasan & \multicolumn{2}{c}{ Belum Tuntas } \\
\hline
\end{tabular}

Tebel 4. Aktivitas Kegiatan Siswa Siklus II

\begin{tabular}{cccc}
\hline Aspek-Aspek Yang Diobservasi & Ya & Tidak & Komentar \\
\hline Jumlah skor & 16 & - & \\
\hline Persentase & 100 & - & \\
\hline Ketuntasan & \multicolumn{3}{c}{ Tuntas } \\
\hline
\end{tabular}

3. Hasil Belajar Siswa

Data hasil perolehan siswa pada siklus I terdapat pada berikut ini

Tebel 4. Kemampuan Menulis Surat Undangan Siswa Siklus I

\begin{tabular}{|c|c|c|c|c|c|c|c|c|}
\hline \multirow{3}{*}{$\begin{array}{c}\text { Kode } \\
\text { Responden }\end{array}$} & \multicolumn{4}{|c|}{ Nomor soal/Aspek/Skor } & \multirow{3}{*}{$\begin{array}{c}\text { Jumlah } \\
\text { skor }\end{array}$} & \multirow{3}{*}{ Nilai } & \multirow{2}{*}{\multicolumn{2}{|c|}{ Ketuntasan }} \\
\hline & $\mathbf{a}$ & $\mathbf{b}$ & c & d & & & & \\
\hline & 3 & 2 & 3 & 2 & & & Ya & Tidak \\
\hline Jumlah & 37 & 25 & 25 & 28 & 208 & 1386.69 & 17 & 5 \\
\hline Skor Maksimal & 44 & 44 & 66 & 44 & 330 & 3300 & 22 & 22 \\
\hline Ketercapaian & 84,0 & 56,8 & 37,8 & 63,6 & 63,03 & 42,02 & 72,73 & 27,27 \\
\hline
\end{tabular}




\begin{tabular}{|c|c|c|c|c|c|c|c|c|}
\hline \multirow{3}{*}{$\begin{array}{c}\text { Kode } \\
\text { Responden }\end{array}$} & \multicolumn{4}{|c|}{ Nomor soal/Aspek/Skor } & \multirow{2}{*}{$\begin{array}{c}\text { Jumlah } \\
\text { skor }\end{array}$} & \multirow{3}{*}{ Nilai } & \multirow{2}{*}{\multicolumn{2}{|c|}{ Ketuntasan }} \\
\hline & $\mathbf{a}$ & b & c & d & & & & \\
\hline & 3 & 2 & 3 & 2 & 10 & & Ya & Tidak \\
\hline$(\%)$ & 9 & 1 & 8 & 4 & & & & \\
\hline Nilai Rata-Rata & & & & & 42,02 & & & \\
\hline
\end{tabular}

Table 6. Kemampuan Menulis Surat Undangan Siswa Siklus 2

\begin{tabular}{|c|c|c|c|c|c|c|c|c|c|}
\hline \multirow{4}{*}{$\begin{array}{c}\text { Nomor } \\
\text { Responden }\end{array}$} & \multicolumn{5}{|c|}{ Nomor Skor } & \multirow{3}{*}{$\begin{array}{l}\text { Jum. } \\
\text { skor }\end{array}$} & \multirow{4}{*}{ Nilai } & \multirow{2}{*}{\multicolumn{2}{|c|}{ Ketuntasan }} \\
\hline & \multicolumn{5}{|c|}{4} & & & & \\
\hline & $\mathbf{a}$ & b & c & d & $\mathbf{e}$ & & & & \\
\hline & 2 & 2 & 2 & 2 & 2 & 15 & & Ya & Tidak \\
\hline Jumlah & 43 & 38 & 33 & 32 & 33 & 180 & 1800 & 20 & 2 \\
\hline Skor Maksimal & 44 & 44 & 44 & 44 & & 330 & 3000 & 22 & 22 \\
\hline $\begin{array}{l}\text { Ketercapaian } \\
(\%)\end{array}$ & $\begin{array}{c}97,7 \\
2\end{array}$ & $\begin{array}{c}86,3 \\
6\end{array}$ & 75 & $\begin{array}{c}72,7 \\
3\end{array}$ & 75 & 81,81 & 81,81 & $\begin{array}{c}90,9 \\
1\end{array}$ & 9,09 \\
\hline Nilai Rata-Rata & & & & & & & & & \\
\hline
\end{tabular}

\section{Pembahasan}

Pada penelitian ini siswa dibagi menjadi 4 kelompok dan tiap kelompok terdiri dari 5 dan 6 orang. Siswa belajar dan bekerja dalam kelompoknya masing-masing dan tiap siswa mempunyai tanggung jawab terhadap teman sekelompoknya, kerena keberhasilan individu/siswa dalam suatu kelompok akan menyumbangkan skor kelompok.

Berdasarkan hasil observasi pada siklus I guru/peneliti dan siswa melakukan sebagian kegiatan pembelajaran dengan baik. Namun demikian masih terdapat kekurangankekurangan yang perlu diperbaiki antara lain pada pelaksanaan tindakan pertama peneliti belum melaksanakan semua proses pembelajaran seperti kegiatan membimbing siswa untuk membuat rangkuman belum terlaksana dan pelaksanaan pembelajaran belum sesuai dengan waktu yang ditentukan serta pemantauan terhadap kegiatan siswa dalam kelompok masih ada yang terabaikan, dan pada pelaksanaan tindakan kedua, peneliti sudah dapat melaksanakan semua proses pembelajaran sesuai waktu yang ditentukan dan pemantauan terhadap kegiatan siswa dalam kelompok sudah mulai optimal terbukti dengan tidak ada kelompok yang terabaikan dalam pemantauan peneliti.

Dan untuk siswa pada pelaksanaan tinakan pertama, siswa terlihat masih asing dengan model pembelajaran yang diterapkan mengingat moel pembelajaran kooperati tipe STAD merupakan hal baru bagi mereka. Hal ini tergambar dari sikap siswa yang masih pasif selama berada dalam kelompok, dan siswa belum bias mengemukakan pendapatnya dan tiak memberikan sanggahan pada saat temannya pada kelompok lain yang berbeda mempresentasikan hasil kerja kelompoknya, serta siswa masih takut jika kelompok/namanya ditunjuk. Dan pada pelaksanaan tindakan kedua, siswa terlihat sudah tidak merasa asing lagi dengan model pembelajaran kooperatif tipe STAD yang diterapkan. Hal ini tergambar dari sikap siswa yang sudah mulai aktif selama berada dalam kelompoknya dan bekerja sama dalam mengerjakan tugas, sebagian siswa belum berani mengemukakan pendapatnya serta masih ada yang takut jika kelompok/namanya ditunjuk.

Hasil evaluasi pada siklus I menunjukkan scenario pembelajaran hanya terlaksana $58,24 \%$ dan peningkatan hasil belajar Bahasa Indonesia setelah diterapkan model pembelajaran kooperatif tipe STAD aalah siswa telah memperoleh nilai $\geq 65$ yaitu hanya $72,73 \%$ dengan nilai rata-rata 42,02 
Cara lain dari pembelajaran kooperatif dan adanya penghargaan yang lebih berorientasi kelompok ketimbang individu. Penghargaan/penguatan yang dimaksud berupa ucapan selamat dan tepuk tangan dari siswa yang ebrsifat spontan terhadap siswa atau kelompok yang memberikan jawaban benar.

Penghargaan lainnya adalah penghargaan tertulis berupa pengumuman mingguan yang berisi tentang ucapan selamat kepada kelompok yang berhasil menempati ranking 1 sampai dengan ranking 3. Pemberian penghargaan/penguatan ini adalah untuk memacu semangat siswa dalam belajar. Penempatan ranking kepada masing-masing kelompok didasarkan pada nilai rata-rata kelompok. Selengkapnya pengumuman mingguan dapat dilihat pada lampiran 8 dan 9.

Bertitik tolak dari kekurangan-kekurangan yang masdih ada dimana skenario pembelajaran baru terlaksana 58,24\% serta ketuntasan belajar Bahasa Indonesia siswa pada tindakan siklus I hanya mencapai $72,73 \%$ seiswa telah memperoleh nilai $\geq 65$, dengan nilai rata-rata 63,03 sehingga belum mencapai indikator keberhasilan dalam penelitian ini, maka penelitian dilanjutkan pada tindakan siklus II. Pada siklus II, model pembelajaran kooperatif tipe STAD kembali dilaksanakan, siswa tetap berada pada kelompoknya sebagaiman pembagian kelompok pada tindakan siklus I.

Berdasarkan hasil observasi pada siklus II, guru dan siswa telah melakukan kegiatan pembelajaran sesuai yang diharapkan. Kekurangan-kekurangan pada siklus I sudah dapat diperbaiki. Guru sudah mampu mengorganisasikan waktu dengan baik sehingga tidak ada lagi kegiatan yang tidak terlaksanakan. Guru/peneliti sudah mampu mengeektifkan pemantauan dan bimbingan siswa terhaap siswa dalam kelompok sehigga tidak ada lagi siswa atau kelompok yang merasa terabaikan. Disamping itu siswa sudah terlihat aktif dalam mengikuti kegiatan pembelajaran serta siswa sudah berani menyampaikan pendapat/gagasannya.

Hasil belajar siswa. Mereka sudah mampu bersosialisasi dengan baik, bahkan sebagian besar siswa sudah berani mengeluarkan pendapat dan menjawab pertanyaan yang diberikan. Ada beberapa siswa yang hingga akhir tindakan siklus memiliki hasil belajar $<65$. Meskipun demikian, mereka memberikan penghargaan dan sikap positif pada saat model pembelajaran kooperatif tipe STAD diterapkan. Hal ini sejalan dengan pendapat yang dikemukakan oleh Nasution (1995:149) bahwa kerja kelompok mempertinggi hasil belajar baik secara kuantitatif maupun kualitatif.

Pada tindakan siklus II, semua skenario pembelajaran telah tercapai dan ketuntasan belajar secara klasikal mencapai $91,91 \%$ siswa memperoleh nilai $\geq 65$, dengan nilai rata-rata 81,81. Karena indikator keberhasilan telah tercapai dalam hal ini telah terlaksananya skenario pembelajaran dan siswa yang memperoleh nilai $\geq 65$ melebihi $70 \%$, maka penelitian ini dihentikan pada tindakan siklus II. Ini berarti hipotesis tindakan telah terjawab yaitu dengan menggunakan model pembelajaran kooperatif tipe STAD hasil belajar bahasa Indonesia standar kompetensi menulis siswa kelas V SD Negeri 11 Loghia dapat ditingkatkan.

Adanya keseragaman waktu kegiatan pembelajaran bahasa Indonesia untuk kelas V SD Negeri 11 Loghia sudah diantisipasi sebelumnya yaitu dengan menformatkan perangkat pembelajaran dan instrumen penelitian sesuai dengan lamanya jam pelajaran untuk setiap kali pelaksanaan tindakan pembelajaran. Sehingga, peningkatan hasil belajar bahasa Indonesia siswa bukan hanya disebabkan oleh lamanya waktu kegiatan pembelajaran di kelas, tetapi dikarenakan model pembelajaran kooperatif tipe STAD yang diterapkan untuk standar kompetensi menulis khususnya menulis surat undangan sudah tepat. 


\section{Simpulan}

Berdasarkan hasil observasi dan evaluasi pada setiap siklus dari penelitian ini, maka dapat disimpulkan bahwa kemampuan menulis surat undangan siswa kelas V SD Negeri 11 Loghia standar kompetensi menulis surat undangan dapat ditingkatkan melalui model pembelajaran kooperatif tipe STAD. Hal ini dibuktikan dengan hasil belajar siswa pada tahun 2016/2017 hanya mencapai 62\% meningkat setelah melakukan PTK siklus I ketuntasan belajar mencapai 72,73\% dengan nilai rata-rata 63,03 dan pada siklus II meningkat menjadi $90,91 \%$ dengan nilai rata-rata 81,81. Aktivitas mengajar guru juga meningkat pada siklus I dari 22 aspek yang diamati 16 aspekatau 72,73\% yang terlaksana pada siklus II keseluruhan aspek yang diamati telah terlaksana dengan maksimal, selanjutnya aktivitas belajar siswa siklus I dari 16 aspek diamati 7 aspek atau 43,75\% yang terlaksana dan pada siklus II keseluruhan aspek yang diamati telah terlaksana dengan maksimal.

\section{Referensi}

Depdiknas. 2004. Kurikulum 2004. Naskah Akademik Mata Pelajaran Bahasa Indonesia. Jakarta: Depdiknas.

Juraini (2016). Pengaruh Model Pembelajaran Kooperatif Tipe STAD (Student Team Achievement Divisio) dengan Metode Eksperimen Terhadap Keterampilan Proses Sains dan Hasil Belajar pada Siswa SMA Negri 1 Labuapi Tahun Pelajaran 2015/2016. Jurnal Pendidikan Fisika dan Teknologi Vol.II No. 2. https://media.neliti.com/media/publications/120389-ID-pengaruh-modelpembelajaran-kooperatif-t.pdf.

Nasution. (1995). Dikdaktik Asas-Asas Mengajar. Jakarta: Bumi Aksara.

Nur Asma. (2006). Model Pembelajaran Cooperative. Jakarta: Depdiknas.

Utami, S. (2015). Peningkatan Hasil Belajar Melalui Pembelajaran Kooperatif Tipe STAD pada Pembelajaran Dasar Sinyal Video. Jurnal Pendidikan Teknologi dan $\begin{array}{lllll}\text { Kejuruan } & \text { Vol. } & 22 & \text { nomor }\end{array}$ https://journal.uny.ac.id/index.php/jptk/article/view/7840/6712.

Pujiati, K., dkk. (2015). Penggunaan Metode Kooperatif Tipe STAD Untuk Meningkatkan Aktivitas dan Ketuntasan Belajar Siswa. Chemistry in Education Vol. 4 Nomor 2. https://journal.unnes.ac.id/sju/index.php/chemined/article/view/6571.

Soewarsono. (1998). Menggunakan Strategi Komparatif Learning di Dalam Pendidikan Ilmu Pengetahuan Sosial: Edukasi. No. 01 hlm 16-25. 